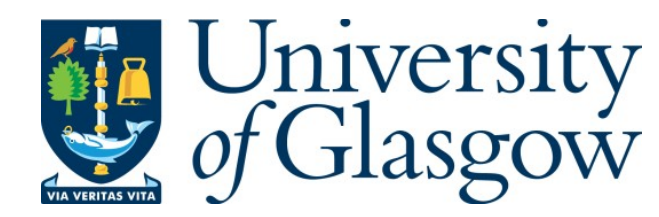

Lusk, K., and Maley, W. (2016) Commemorating Connolly: contexts, comparisons and Celtic connections. Irish Studies Review, 24(4), pp. 385-395.

There may be differences between this version and the published version. You are advised to consult the publisher's version if you wish to cite from it.

http://eprints.gla.ac.uk/124242/

Deposited on: 19 September 2016

Enlighten - Research publications by members of the University of Glasgow http://eprints.gla.ac.uk 


\title{
Commemorating Connolly: Contexts, Comparisons and Celtic Connections
}

\author{
Kirsty Lusk and Willy Maley \\ English Literature, University of Glasgow, Glasgow, Scotland
}

Email: k.lusk.1@research.gla.ac.uk

Email:Willy.Maley@glasgow.ac.uk

\begin{abstract}
Now traditions may, and frequently do, provide materials for a glorious martyrdom, but can never be strong enough to ride the storm of a successful revolution. If the national movement of our day is not merely to re-enact the old sad tragedies of our past history, it must show itself capable of rising to the exigencies of the moment. It must demonstrate to the people of Ireland that our nationalism is not merely a morbid idealizing of the past, but is also capable of formulating a distinct and definite answer to the problems of the present and a political and economic creed capable of adjustment to the wants of the future. ${ }^{1}$
\end{abstract}

So wrote James Connolly in his 1897 article “Socialism and Nationalism”. It was Connolly’s opinion that commemoration as a method of “crystallising nationalism into a tradition” was unhelpful if it caused the "neglect of vital living issues”. Ellen Carol Jones detects in James Joyce’s reservations about remembrance an echo of Connolly’s cautionary note:

James Connolly argued that nationalist and revivalist programs and projects, by invoking a usable past to serve the present, vitiated the political will of the populace and obfuscated their goal of political emancipation, thereby effecting martyrdom but not revolution. Parodied in Ulysses, such nationalist spectacles of mourning, 
commemoration, and vicarious resistance functioned as pap for the dispossessed. Joyce’s parodies of late nineteenth- and early twentieth-century commemorative rituals, while they acknowledge how such spectacles have become historical forces in their own right, also act as explosive de-commemorations. ${ }^{2}$

Yet Connolly acknowledged that commemoration societies, along with language and literary societies performed “a work of lasting benefit to this country in helping to save from extinction the precious racial and national history, language and characteristics of our people”. Jones is aware of the contradictions in Connolly's position, which are also the tensions explored in this collection, itself a commemoration that questions commemoration. As Jones observes of Connolly's subsequent call for the centenary of 1798 to be marked in his article “The Men We Honour”, published in the first issue of The Workers' Republic on 13 August 1898:

Echoing the nationalists' idealization of Wolfe Tone as the author of liberty, James Connolly linked the social and economic revolution he envisioned with the political revolution Wolfe Tone had hoped to achieve: "When the hour of the Social Revolution at length strikes and the revolutionary lava now pent up in the Socialist movement finally overflows and submerges the kings and classes who now rule and ruin the world, high up in the topmost niches of the temple a liberated human race will erect to the heroes and martyrs who have watered the tree of liberty with the blood of their body and the sweat of the intellect [a monument and] a grateful Irish people will carve the name of our precursor, Theobald Wolfe Tone”. ${ }^{3}$ 
As Maria Dick suggests in her contribution to this collection, we would be wise not to prematurely yoke the two Jameses together, whatever their affinities.

Conor Cruise O’Brien’s chronology and genealogy of Connolly’s conversion to commemoration is a little different, and for O’Brien the language of martyrdom once mocked by Connolly takes over as he comes under the influence of the leader of the rising most associated with the politics of sacrifice:

The socialist, James Connolly, had earlier sneered at Pearse’s sacramental exaltation of "the red wine of the battlefield." But by 1916 Connolly is talking in exactly the same vein, as if he had been mesmerised by Pearse. ${ }^{4}$

It seems ironic, then, but perhaps also fateful, that through the act of commemoration and through literary and dramatic works, Connolly himself has become an oft-cited symbol to crystalize the nationalist tradition.

In his native Scotland, Connolly is primarily remembered as a trade unionist - if he is remembered at all. In Ireland, it is as a nationalist martyr that Connolly is celebrated. Different traditions seek out the aspects of Connolly that best conform to their focus, adopting him as a symbol, yet Connolly himself is such a complex figure that there are few traditions that accept Connolly as man, as writer, as activist, not just as symbol. The late Ian Bell, Connolly’s great nephew, put it simply: "Connolly has been too damned difficult”. ${ }^{5}$ Or to put it differently, "Scotland chooses to forget James Connolly while Ireland holds him in a vice of approved memory". ${ }^{6}$ Yet in the wake of the referendum on Scottish independence it is timely to reconsider Edinburgh-born James Connolly as a key crossover figure for Irish and Scottish perspectives on independence. There is a still growing body of criticism on Connolly that sees him as primarily an Irish figure, and further work will appear in 2016 and beyond 
with an exclusively Irish focus. Ironically, Connolly’s father moved to Edinburgh’s “Little Ireland” from the "Scotstown” area of Ballybay, County Monaghan. Connolly’s motivation, background, politics and Scottish connections have yet to be thoroughly explored, perhaps because they threaten to challenge official histories of the Rising. In Scotland, comparisons with Ireland are always uneasy thanks to the sectarian shame that remains a divisible presence in the country. Yet without this comparison, there can be no thorough interrogation and understanding of Scotland, and similarly, to focus on Anglo-Irish studies and overlook Irish-Scottish studies is a narrow approach, which disregards one of the most important relationships - for, better or worse - for Ireland. Far too frequently are the terms "British" and "English” used interchangeably in Irish studies even now. To focus on James Connolly as a Celtic connection and to examine how Connolly has been commemorated over the years is a step in refiguring our understanding of Irish-Scottish relations, particularly in terms of politics, memory and literature, and the steps and missteps towards reconciliation.

The pioneering work of Owen Dudley Edwards on Connolly helped establish his cross-cultural Celtic credentials:

The first thing to remember about James Connolly and Irish tradition is that he was born outside it. He was Edinburgh born, his parents were Monaghan emigrants to Edinburgh; but as an Irish emigrant to Edinburgh I myself can testify to the remoteness of the Irish emigrant's background against his Scottish children’s perceptions of their Edinburgh actuality. Looking up from the squalid and almost lightless depths of the Cowgate, the young Connolly could learn Marxism simply by seeing the stately folk walking far above him on the fashionable George IV Bridge which swept above the slums below. He could see he was a proletarian long before he could hear he was Irish. ${ }^{7}$ 
Here, Edwards emphasises Connolly’s Edinburgh upbringing as key to his socialism. In this collection, Niall O’Gallagher establishes the lasting influence of Connolly on a Gaelic writer of the stature of Sorley MacLean. Elsewhere, James Kelman has tracked Connolly’s intellectual formation through the radical Scottish thinkers of the nineteenth century. ${ }^{8}$

According to James D. Young, Connolly kept abreast of Scottish events and was in contact with Red Clydesider John Maclean:

Connolly was aware of what was happening on Red Clydeside. In the 20 November, 1915 issue of the Workers’ Republic, he attacked the suppression of “Free Speech in Scotland”. In appealing for workers’ agitation on Maclean’s behalf, Connolly was more interested in organising a Nationalist revolt in Dublin against British imperialism. At much the same time, he published an article entitled "Glasgow Gaels Will Fight” in which he reported on a meeting in the Sinn Féin Hall, London Street, Glasgow. Depicting the annual commemoration of the Manchester Martyrs, he enthused about "the gathering of exiles, some born in Ireland, some out of Ireland including several Fenian veterans" who were most anxious to "strike the British Empire in a vital spot”.9

The culture of commemoration around the Manchester Martyrs, of which James Connolly's only surviving drama is a compelling instance, is a crucial example of rapid response remembrance. $^{10}$

Irish historians continue to wrestle with the legacy of legacies, with "remembrance history”, antiquarianism and the status of the archive. ${ }^{11}$ Recent work on the history, politics and culture of commemoration has taught us to be attentive to the uses and abuses of memory 
as well as to the often-conflicting urges to remember, revise and resolve. ${ }^{12}$ Efforts to combine remembrance and reconciliation are fraught with difficulty. As Guy Beiner cautions: “Newly formulated expressions of ecumenical sharing of trauma may ultimately carry less resonance than sectarian evocations of trauma that entail a spirit of triumphalism”. ${ }^{13}$ In order to access the “deep memory” that gives rise to profound passions, we need to go beyond official commemorations and look at the ways in which the rhetorics of remembrance not only impinge upon but, crucially, are produced by popular memory: “Traditions of commemoration reflected in the 'collected memory' of folklore accounts challenge current academic perceptions of 'collective memory’ and offer insights into the more composite dynamics of social memory”. ${ }^{14}$ The archive of popular memory is found in places other than stone and statuary. This was as true of 1798 as of 1916: "More often than not, local commemoration was manifested in mundane, rather than monumental, deeds and expressions. Souvenirs from the period served as aides-mémoire through which 1798 was remembered in numerous households”. ${ }^{15}$ Guy Beiner’s “green” or environmentally friendly approach to commemoration is one we find instructive. Equally instructive is the fact that if history repeats itself, then perhaps Irish history repeats itself more than others, since the prelude to both the 1798 and 1916 risings was a flourishing of national cultural forms. ${ }^{16}$ Joep Leerssen has written eloquently on this double bind or self-fulfilling prophecy with regard to 1798 , a precursor of 1916:

The violence and turmoil of 1798 made sense in one aspect only: its recurrent nature. [...] Once seen as a link in the chain of conflicts characterizing Irish history since the Middle Ages, 1798 therefore inspired nineteenth-century historical awareness in a twofold way: on the one hand, because people came to view conflict as a recurrent, normal mode for historical development, and on the other hand, because it fixed a 
sense that in Ireland such crises ended in attrition and defeat rather than in resolution. $^{17}$

Likewise, Eugene McNulty argues that commemoration is defined as much by exclusion as identity: "To fully understand the dynamics of a commemorative moment [...] we must look not simply to the version of the past recalled; just as revealing is the manner in which we either take control of or are excluded from the physical spaces of remembrance”. ${ }^{18}$

Remembrance is risky, and can give rise to action rather than merely passively recalling events. ${ }^{19}$ Sometimes the action that statues bring to life is unexpected, and emanates from those who resent rather than revere the monument. As Anne Fogarty observes, reflecting on Joyce’s suspicion of monumental history:

"The fact that the statue of Tone was erected eventually in 1967 on a different corner of St. Stephen's Green to the one marked out in 1898 only to be blown up some four years later by a loyalist bomb indicates the continuing relevance of the Joycean motif of the self-erasing but uncanny presence of the 1798 rising, the legacy of which is at once enduring, problematic and in need of constant critical re-investigation”. ${ }^{20}$

Yet amnesia, enforced or accidental, has its pitfalls too. As Gabriel Doherty remarks of the decision to commemorate the centenary of O’Donovan Rossa's funeral and the warnings it solicited of encouraging sectarianism or damaging community relations: "The real damage would surely have been done had the state not organised such a commemoration, for it would have signified, at the very outset of the commemorative programme, that every aspect of the content and tone of that programme would be sacrificed to contemporary considerations”. ${ }^{21}$ Yet the centenary commemorations of O’Donovan Rossa’s funeral demonstrate something of the continued divisions within Ireland. After the state 
commemorations concluded, Sinn Fein held their own commemoration complete with cortege. As such "contemporary considerations” are clearly a persistent pressure on the politics of commemoration, yet these considerations are different within alternative political and cultural strands. As John Turpin observed:

The eruption in 1968 of political violence in Northern Ireland eventually diminished public interest in commemorating the 1916 Rising and War of Independence in the Republic. Once safely commemorated as historical events, those events had now become all too contemporary and real. ${ }^{22}$

It could be argued of course that there is no such thing as safe commemoration, and that the contemporary and real always intrude. The 1972 bombing of Wolfe Tone's statue in Dublin was preceded by the 1966 bombing of Nelson's statue in the same city. One community’s tribute is another's sign of tyranny.

According to the $O E D$, “commemoration" means to "mention as worthy of remembrance; to make eulogistic or honourable mention of; to celebrate in speech or writing”, or to "call to remembrance, or preserve in memory, by some solemnity or celebration". These definitions raise some of the challenges and questions that come with commemoration of Easter 1916. The concept that an event must be “worthy of commemoration” draws attention to the differing events of 1916 that are commemorated within Scotland and Ireland: the First World War, specifically the Battle of the Somme, and the Easter Rising. As Kevin Rooney maintains:

The politics of remembrance has always been political, as the story of the founding of the modern Irish state and the partition of Ireland makes clear. Remembrance Day, 
and remembrance of World War One more generally was a card to play in defence of the new political arrangement, and a commemoration to be viewed with suspicion by those for whom 1916 was more about the GPO than the Somme. ${ }^{23}$

Rooney’s view is shared by Richard Grayson, who points out that “from 1917 onwards there was a strong unionist focus on Somme remembrance [...] the story of the Somme became absolutely central in the creation of inter-war unionism, with many unionist writers pointing out the contrasts between the activities of loyal Ulstermen on the Somme in 1916, and the rebellion in Dublin in the same year”. ${ }^{24}$ Yet it can also be argued - as has Nils Arne Sørensen - that the spoils and sacrifices of 1916 were shared:

[F]rom 1916 the Irish were engaged in both the world war and a war against the British. To make things even more complex, the latter was also to a high degree a civil war where the Irish soldiers in the British army (and their relatives) and the Volunteers (and their relatives) in reality became foes although not actually fighting against each other. Both groups came out of "their” war as victors. Britain was among the victorious powers of 1918 and the radical nationalists eventually gained something very close to Irish independence in 1922. The two narratives of war and victory were, however, impossible to blend into a single master narrative. ${ }^{25}$

Garth Stevenson offers another angle on 1916 and commemoration when he suggests that the wounds of the subsequent civil war were healed in part by the shared experience of the Easter Rising: 
The treaty of 1921 seemed [...] like a betrayal of those who had sacrificed themselves in 1916. Yet some who supported the treaty on pragmatic grounds had also participated in the Rising. Because 1916 was a memory shared by both sides, it perhaps contributed to the healing of the nation's wounds and the establishment of a stable democracy. ${ }^{26}$

Despite being presented as a coming together, commemoration often entails taking sides. One state's remembrance of the achievements of empire is another community's recollection of anti-colonial resistance:

Nelson and Wellington are remembered through columns and obelisks, '98 rebels are represented through Celtic crosses and peasants carrying pikes. This use of symbols is drawing from two differing traditions, one from ancient Roman iconography, the other from Celtic iconography. This did not happen accidentally - those remembering ' 98 were doing so in the context of the Celtic and Gaelic revival of the 1890s and they chose symbols which they saw as offering historical continuity with this earlier world. By contrast, the use of Roman columns and images of Britannia harkened back to icons used by the victorious in a more ancient imperial realm and made connections with this history. ${ }^{27}$

It is perhaps the personal aspect of remembrance that makes it so political. Frank McGuinness' Pyper in Observe the Sons of Ulster Marching Towards the Somme calls to the ghosts of his comrades and appeals to his audience: "What sense could you make of their sacrifice? I at least continued their work in this province. The freedom of faith they fought 
and died for would be maintained. There would be, and there will be no surrender". ${ }^{28}$ Easter 1916 and the Battle of the Somme have been culturally figured as blood sacrifices for two different, often opposing, political and ideological strands. Yet the initial reaction to the Rising was negative in Dublin because of the number of Irish soldiers fighting abroad. 200,000 Irishmen fought in the First World War and 49,000 were killed. ${ }^{29}$ It is important to recall that the Rising was an anti-imperialist movement, as much as it was a rebellion for independence. As the sign outside Liberty Hall declared: "We Serve Neither King Nor Kaiser but Ireland”. It was a declaration of anti-imperialist, anti-war intent. On a personal, rather than a political level, the divide was not so extensive as modern politics would suggest. John Redmond's Irish Volunteers fought with the British Army in the belief that doing so would secure Home Rule. Poet Francis Ledwidge, friend of Thomas MacDonagh, wrote “O’Connell Street”, in France in June 1917, with its final line: “For mine are all the dead men’s dreams”. ${ }^{30}$ Ledwidge was killed in the Battle of Passchendaele on July $31^{\text {st }} 1917$. For Connolly, there was also a personal link. Ina Connolly’s statement to the Bureau of Military History Archives reads: “My father had a brother, John, older than himself. He was prominent in local politics in Edinburgh when father was a little boy and it was he who was expected to distinguish himself in that sphere. He entered the British army as a young man and died about June 1916 and was buried with British military honours”. ${ }^{31}$ These personal aspects have been largely forgotten however, as the political comes to the fore with the distance of time. In 1966 the "official commemorations at the GPO were ostentatious” and “RTE broadcast Yeats’s Cathleen ni Houlihan” which concludes with Michael Gillane sacrificing himself for Ireland, valuing masculinity and blood sacrifice. Higgins, Holohan and O’Donnell note that 
In contrast to the Republic, the commemoration of the fiftieth anniversary of the Easter Rising in Northern Ireland was not an official state-sponsored event. Instead, the fiftieth anniversary of the Battle of the Somme enjoyed official status there in the summer of 1966. Only the nationalist community celebrated the anniversary of the Rising, and the decision by the Northern Ireland government not to place a blanket ban on the Easter celebrations met with some opposition from within unionism. ${ }^{32}$

Indeed, the Reverend Ian Paisley was amongst the most vocal against the Easter Rising commemorations and organized a counter "thanksgiving” for the defeat of the rebels. ${ }^{33}$ Commemoration became bound up in contemporary politics, becoming yet another issue for politicians to utilize to their benefit or, as for Terence O’Neill, their undoing. In Scotland, acts of remembrance were more muted but still troubled. The fate of a commemorative tribute in Edinburgh's Cowgate exemplified the difficulty of commemorating Connolly: "The first version of the Connolly plaque was levered from its grimy wall almost as soon as it was unveiled". 34

By the $75^{\text {th }}$ anniversary commemorations in 1991, the question of "celebration” had risen to the fore. The "troubles" of the 1970s and 1980s changed responses to 1916, at home and abroad. Helen Clark arranged the Sing a Rebel Song exhibition in Connolly's native Edinburgh:

Not all visits however were welcome; some young men stormed in, and wanted to know the name of the person who set up the exhibition so they could "fill them in". On a similar note, in the People's Story Museum we have a panel with a photo of 
James and Lillie Connolly with their daughters Mona and Nora. This photo was slashed with a knife in about $1992 .^{35}$

In Ireland, "official commemorations of the seventy-fifth anniversary of the rebellion remembered the Rising in a [...] subdued and half-hearted way”. ${ }^{36}$ There was, according to James Moran, a “discursive silence about the uprising”. ${ }^{37}$ Conor Cruise O’Brien saw “something hesitant and mostly subliminal, tinged with apprehension and with 'guilt"”. 38 This was a clear difference to the commemorations in 1966: "Only in the following years, once the embers of sectarian hatred had been fanned into full conflagration in the North of Ireland, did the Rising appear a less appetizing subject, thanks largely to the O’Brienite thesis that the modern IRA was descended from the Easter rebellion”. ${ }^{39}$ This is something that has shifted again with the centenary commemorations of Easter Week, particularly through literature, as an attempt towards reconciliation has been made. Dublin’s “One City, One Book” has been altered to “Two Cities, One Book” for 2016, twinning Dublin with Belfast. Lia Mills' Fallen is an excellent choice as a reconciliatory text that also succeeds in bringing civilian women and Irish soldiers fighting abroad back into the narrative of 1916. It questions violence and war and legacies that they create for those left behind. ${ }^{40}$ In Glasgow, in June 2016, Peter Arnott's Shall Roger Casement Hang? and Frank McGuinness's Observe the Sons of Ulster Marching Towards the Somme, were performed simultaneously. Literature and drama can be described as commemorative efforts, but they not only "preserve in memory”, they question and critique even as they remember.

In Ireland, as Rooney states, commemoration and politics are entwined. In 1966, Seamus Heaney and C. Day-Lewis both focused on commemoration for their poems on 1916, yet in very different manners. Heaney’s ‘Requiem for the Croppies’ was ‘written in 1966 when 
most poets in Ireland were straining to celebrate the anniversary of the 1916 Rising' and harked back to the earlier 1798 rebellion, influenced perhaps by Cathleen ni Houlihan. DayLewis’s “Kilmainham Jail: Easter Sunday 1966” concentrates on the fiftieth anniversary itself. The persona holds an uneasy relationship with the act of commemoration, noting that “Against the wall where once / Connolly strapped to a chair, was shot, a platform / Holds movie cameras” and that commemorative ephemera, "only cheapen their cause”. ${ }^{41}$ It worries, as Connolly did, that the commemoration is "crystallising tradition" and instead asks for a true honouring of the dead men by achieving their ideals: "The fourteen men. Let them be more than a legend: / Ghost voices of Kilmainham, claim your due - / This is not yet the Ireland we fought for. / You living, make our Easter dreams come true”. ${ }^{42}$ Day-Lewis echoes Connolly, whose question in "The Call to Arms" (1916) is equally applicable: "So endeth the first chapter. Who will write the next?"43

This special issue of Irish Studies Review is part of the next chapter of Connolly studies. Our contributors interrogate the culture of commemoration around Connolly from a variety of perspectives. Maria Dick explores the depiction of Connolly by James Joyce in order to draw out the complexities and contradictions of the cultures of commemoration and remembrance that fascinated and perplexed both figures. Aaron Kelly mounts a spirited defence of Connolly in the face of criticisms from revisionists and socialists alike, elaborately demonstrating that Connolly’s Marxism is as relevant and as rigorous today as it was when he first argued eloquently for independence and against empire. The anti-colonial aspect of Connolly’s socialism - and Connolly's consistency in combining critique of empire with a call for independence - is crucial too for Kirsty Lusk, who finds clarity and connectivity across Connolly's writings, exemplified by the drama of taking sides in Under Which Flag?, Connolly’s play of the 1867 Fenian Rising, read here alongside Yeats and Gregory’s staging of the 1798 Rising, Cathleen ni Houlihan. Robbie McLaughlan takes a comparative approach 
and homes in on the forms of resistance adopted in anti-imperial conflicts in two of Britain's oldest colonies, India and Ireland, contrasting Gandhi’s peaceful methods with Connolly’s pursuit of independence through armed struggle. Niall O’Gallagher comes at Connolly’s Irish-Scottish inheritance from a different angle, closer to home, focusing on the radical Gaelic poet Sorley MacLean’s adoration of Connolly and justification of his legacy of physical force nationalism. Alison O’Malley-Younger looks at the ways in which events around the centenary of the 1798 rebellion acted as a catalyst for 1916, in terms of consciousness-raising, commodification and cultural awareness, and in the celebration of prominent individuals such as Wolfe Tone and Connolly. Marking 1916 meant marketing as well as memorializing. Gerry Smyth provides insights of another kind in his fraternal comic dialogue in the spirit of Flann O’Brien, making connections with remembrance and witnessing and flagging up suggestively a link between 1916 and 1917 that Lenin and Trotsky’s rich reflections on the Easter Rising would justify. ${ }^{44}$

In his critique of "the cult of the centenary", Roland Quinault suggests, as others have done, that commemoration begets commemoration, but also that we need to view commemoration in context - in relation to other acts of remembrance, and alongside others' acts of remembrance:

The '98 commemoration, together with the 1903 centenary of Robert Emmet's rebellion, encouraged the rise of Sinn Fein, the creation of the Dungannon Clubs and the revival of the Irish Republican Brotherhood. But the success of the '98 commemoration reflected not only the appeal of republican nationalism, but also the current international enthusiasm for centenary celebrations. ${ }^{45}$ 
A cult of commemoration - or a cult of Connolly - is not something that the subject of this

collection would have approved. Our purpose, if we have one in the singular, is to suggest

that reading is the best form of remembrance, even if that reading is as varied and contested

as the events and individuals to which it is addressed. Commemorating Connolly is one thing.

Engaging critically with his complex legacy, including his writings, is another matter.

\section{Bibliography}

Beiner, Guy. “Negotiations of Memory: Rethinking 1798 Commemoration”. The Irish Review 26 (2000): 60-70. Beiner, Guy. "Recycling the Dustbin of Irish History: The Radical Challenge of 'Folk Memory'”. History Ireland 14, no. 1 (2006): 42-47.

Beiner, Guy. "Between Trauma and Triumphalism: The Easter Rising, the Somme, and the Crux of Deep Memory in Modern Ireland". Journal of British Studies 46, no. 2 (2007): 366-389.

Beiner, Guy, and Joep Leerssen. "Why Irish History Starved: A Virtual Historiography”. Field Day Review 3 (2007): 66-81.

Bell, Ian. "Connolly and Independence". In Scotland and the Easter Rising: Fresh Perspectives on 1916, edited by Kirsty Lusk and Willy Maley, 37-41. Edinburgh: Luath Press, 2016.

Bort, Eberhard. Ed. Commemorating Ireland: History, Politics, Culture. Dublin: Irish Academic Press, 2004.

Burke, Helen M. "The Revolutionary Prelude: The Dublin Stage in the Late 1770s and Early 1780s".

Eighteenth-Century Life 22, no. 3 (1998): 7-18.

Busteed, Mervyn. "Parading the Green - Procession as Subaltern Resistance in Manchester in 1867”, Political Geography 24 (2005): 903-933.

Connolly, James. "Socilaism and Nationalism”. In James Connolly: Selected Writings, edited by Peter

Berresford Ellis, 121-124. London: Pluto, 1997.

Connolly, James, “The Call to Arms” (1916), from Workers' Republic,

https://www.marxists.org/archive/connolly/1916/04/callarms.htm

Clark, Helen. "Commemorating Connolly in 1986”. In Scotland and the Easter Rising: Fresh Perspectives on 1916, edited by Kirsty Lusk and Willy Maley, 67-73. Edinburgh: Luath Press, 2016.

Day-Lewis, Cecil. “Kilmainham Jail: Easter Sunday, 1966”. In An Anthology of Modern Poetry, edited by Wes Davis, 58-59. London: Belknap Press, 2010.

Doherty, Gabriel. “O’Donovan Rossa Funeral Centenary: To Commemorate or Not to Commemorate?” History Ireland 23, no. 6 (2015): 10-11.

Dolan, Anne. Commemorating the Irish Civil War: History and Memory, 1923-2000. Cambridge: Cambridge University Press, 2003.

Ireland's Memorial Records, http://imr.inflandersfields.be/index.html

Edwards, Owen Dudley. “Connolly and Irish Tradition”. The Furrow 30, no. 7 (1979): 411-424.

Fogarty, Anne. “'Where Wolfe Tone’s statue was not': Joyce, 1798 and the Politics of Memory”. Études irlandaises 24, no. 2 (1999): 19-32.

Grayson, Richard S. "From Genealogy to Reconciliation: Public Engagement with Remembrance of the First World War in Ireland”. Nordic Irish Studies 13, no. 2 (2014): 99-113.

Heron, Ina, “Witness Statement 919”, Bureau of Military History Archives 1913-21, http://www.bureauofmilitaryhistory.ie/reels/bmh/BMH.WS0919.pdf

Higgins, Roisín, Carole Holohan and Catherine O’Donnell. “1966 and All That: The 50th Anniversary Commemorations”. History Ireland 14, no. 2 (2006): 31-36.

Jarman, Neil, and Dominic Bryan. "Green Parades in an Orange State: Nationalist and Republican Commemorations and Demonstrations from Partition to the Troubles, 1920-70.” In The Irish Parading Tradition: Following the Drum, edited by T. G. Fraser, 95-110. London: Palgrave Macmillan, 2000. Johnson, Nuala C. "Sculpting Heroic Histories: Celebrating the Centenary of the 1798 Rebellion in Ireland." Transactions of the Institute of British Geographers 19, no. 1 (1994): 78-93. 
Jones, Ellen Carol. “History’s Ghosts: Joyce and the Politics of Public Memory.” Journal of Irish Studies 25 (2010): 3-17.

Kelman, James. “A Slant on Connolly and the Scotch Ideas”. In Scotland and the Easter Rising: Fresh

Perspectives on 1916, edited by Kirsty Lusk and Willy Maley, 114-123. Edinburgh: Luath Press, 2016.

Ledwidge, Francis. “O’Connell Street”. In The Complete Poems of Francis Ledwidge, edited by Alice Curtayne, 154. London: Martin Brian \& O'Keeffe, 1974.

Leerssen, Joep. Remembrance and Imagination: Patterns in the Historical and Literary Representation of Ireland in the Nineteenth Century. Cork: Cork University Press, 1996

Leerssen, Joep. “1798: The Recurrence of Violence and Two Conceptualizations of History”. The Irish Review 22 (1998): 37-45.

Lenin, V. I. “The Irish Rebellion of 1916”. In Lenin on Britain, 256-260. Moscow: Progress Publishers, 1979. McBride, Ian, ed., History and Memory in Modern Ireland. Cambridge: Cambridge University Press, 2001.

McCarthy, Mark. Ireland's 1916 Rising: Explorations of History-Making, Commemoration \& Heritage in Modern Times. Abingdon: Routledge, 2012.

McGuinness, Frank. Observe the Sons of Ulster Marching Towards the Somme. London: Faber \& Faber, 1986. McIntosh, Gillian. The Force of Culture: Unionist Identities in Twentieth-Century Ireland. Cork: Cork University Press, 1999.

McNulty, Eugene. “The Place of Memory: Alice Milligan, Ardrigh, and the 1898 Centenary”. Irish University Review 38, no. 2 (2008): 203-221.

Mark-Fitzgerald, Emily. Commemorating the Irish Famine: Memory and the Monument. Liverpool: Liverpool University Press, 2013.

Mills, Lia. Fallen. Dublin: Penguin Ireland, 2016.

Moran, James, Staging the Easter Rising: 1916 as Theatre. Cork: Cork University Press, 2005.

Nititham, Diane Sabenacio, and Rebecca Boyd, eds. Heritage, Diaspora and the Consumption of Culture:

Movements in Irish Landscapes. Farnham, Surrey: Ashgate, 2014.

O’Brien, Conor Cruise. Ancestral Voices: Religion and Nationalism in Ireland. Chicago: University of Chicago Press, 1995.

Pine, Emilie. “The Tyranny of Memory: Remembering the Great War in Frank McGuinness’s Observe the Sons of Ulster Marching Towards the Somme”. Irish University Review 40, no. 1 (2010): 59-68.

Quinault, Roland. “The Cult of the Centenary, c.1784-1914”. Historical Research 71, no. 176 (1998): 303-323. Rooney, Kevin. “'Let the People Sing': Rebel Songs, the Rising and Remembrance”. In Scotland and the Easter Rising, edited by Kirsty Lusk and Willy Maley, 168-173. Edinburgh: Luath Press, 2016.

Sørensen, Nils Arne. "Commemorating the Great War in Ireland and the Trentino: An Essay in Comparative History”. Nordic Irish Studies 2 (2003): 121-139.

Stevenson, Garth. "The Politics of Remembrance in Irish and Quebec Nationalism”. Canadian Journal of Political Science/Revue canadienne de science politique 37, no. 4 (2004): 903-925.

Trotsky, Leon. “On the Events in Dublin”. https://www.marxists.org/archive/trotsky/1916/07/dublin.htm. Accessed 16 August 2016.

Turpin, John. "Monumental Commemoration of the Fallen in Ireland, North and South, 1920-60”. New Hibernia Review/Iris Éireannach Nua 11, no. 4 (2007): 107-119

Walker, Brian. “1641, 1689, 1690 and All That: The Unionist Sense of History”. The Irish Review 12 (1992): 56-64.

Young, James D. “John Maclean, Socialism and the Easter Rising”. Saothar 16 (1990): 23-33.

\footnotetext{
1 James Connolly, “Socialism and Nationalism”, 121.

${ }^{2}$ Ellen Carol Jones, “History’s Ghosts: Joyce and the Politics of Public Memory”, 12.

3 Jones, "History’s Ghosts', 15 n.17.

${ }^{4}$ Conor Cruise O’Brien, Ancestral Voices: Religion and Nationalism in Ireland, 112. O’Brien dates Connolly’s conciliation with Catholic martyrdom and the concomitant shift from socialism to nationalism to 1914: "From
} 
the outbreak of war on, Connolly is becoming more and more 'old-fashioned' and less and less "newfangled”' O’Brien, Ancestral Voices, 113.

${ }^{5}$ Ian Bell, “Connolly and Independence”, 38.

${ }^{6}$ Bell, “Connolly and Independence”, 40.

${ }^{7}$ Owen Dudley Edwards, “Connolly and Irish Tradition”, 411.

${ }^{8}$ James Kelman, “A Slant on Connolly and the Scotch Ideas”.

${ }^{9}$ James D. Young, “John Maclean, Socialism and the Easter Rising”, 26.

${ }^{10}$ For an excellent account of the speed with which the executions were marked see Mervyn Busteed, "Parading the Green - Procession as Subaltern Resistance in Manchester in 1867”.

${ }^{11}$ Examples include Anne Dolan, Commemorating the Irish Civil War: History and Memory, 1923-2000; Joep Leerssen, Remembrance and Imagination: Patterns in the Historical and Literary Representation of Ireland in the Nineteenth Century; Ian McBride, ed., History and Memory in Modern Ireland; Mark McCarthy, Ireland's 1916 Rising: Explorations of History-Making, Commemoration \& Heritage in Modern Times; Emily MarkFitzgerald, Commemorating the Irish Famine: Memory and the Monument; and Diane Sabenacio Nititham and Rebecca Boyd, eds. Heritage, Diaspora and the Consumption of Culture: Movements in Irish Landscapes. For an excellent discussion of recent developments in historiography that impact on Irish studies see Guy Beiner and Joep Leerssen, "Why Irish History Starved: A Virtual Historiography”.

${ }^{12}$ See for example Guy Beiner, "Negotiations of Memory: Rethinking 1798 Commemoration”; "Recycling the Dustbin of Irish History: The Radical Challenge of 'Folk Memory””; "Between Trauma and Triumphalism: The Easter Rising, the Somme, and the Crux of Deep Memory in Modern Ireland”.

${ }^{13}$ Beiner, "Between Trauma and Triumphalism”, 389. See also Neil Jarman and Dominic Bryan, “Green Parades in an Orange State: Nationalist and Republican Commemorations and Demonstrations from Partition to the Troubles, 1920-70."

${ }^{14}$ Beiner, "Negotiations of Memory”, 69.

${ }^{15}$ Beiner, "Recycling the Dustbin of Irish History", 47.

${ }^{16}$ Helen M. Burke, “The Revolutionary Prelude: The Dublin Stage in the Late 1770s and Early 1780s”.

${ }^{17}$ Joep Leerssen, “1798: The Recurrence of Violence and Two Conceptualizations of History”, 37.

${ }^{18}$ Eugene McNulty, “The Place of Memory: Alice Milligan, Ardrigh, and the 1898 Centenary”, 205.

${ }^{19}$ See Nuala C. Johnson, "Sculpting Heroic Histories: Celebrating the Centenary of the 1798 Rebellion in Ireland”, 92.

${ }^{20}$ Anne Fogarty, “'Where Wolfe Tone’s statue was not’: Joyce, 1798 and the Politics of Memory”, 31.

${ }^{21}$ Gabriel Doherty, “O’Donovan Rossa Funeral Centenary: To Commemorate or Not to Commemorate?”, 10-11.

22 John Turpin, “Monumental Commemoration of the Fallen in Ireland, North and South, 1920-60”, 111.

${ }^{23}$ Kevin Rooney, “'Let the People Sing': Rebel Songs, the Rising and Remembrance”, 169-70.

${ }^{24}$ Richard S. Grayson, "From Genealogy to Reconciliation: Public Engagement with Remembrance of the First World War in Ireland”, 101. Grayson cites Gillian McIntosh, The Force of Culture: Unionist Identities in Twentieth-Century Ireland, 15-16. For another view of the unionist approach to commemoration see Brian Walker, "1641, 1689, 1690 and All That: The Unionist Sense of History”.

${ }^{25}$ Nils Arne Sørensen, "Commemorating the Great War in Ireland and the Trentino: An Essay in Comparative History”, 124.

${ }^{26}$ Garth Stevenson, “The Politics of Remembrance in Irish and Quebec Nationalism”, 920.

${ }^{27}$ Nuala C. Johnson, Nuala C. "Sculpting Heroic Histories: Celebrating the Centenary of the 1798 Rebellion in Ireland”, 92.

${ }^{28}$ Frank McGuinness, Observe the Sons of Ulster Marching Towards the Somme, 10. For a superb discussion of the rhetoric of remembrance and the work of mourning in this play see Emilie Pine, "The Tyranny of Memory:

Remembering the Great War in Frank McGuinness’s Observe the Sons of Ulster Marching Towards the Somme".

${ }^{29}$ Ireland's Memorial Records, http://imr.inflandersfields.be/index.html

${ }^{30}$ Francis Ledwidge, “O’Connell Street”.

${ }^{31}$ Ina Heron, "Witness Statement 919”, 1.

${ }^{32}$ Higgins, "1966 and All That”, 31.

${ }^{33}$ Higgins, "1966 and All That”, 36.

${ }^{34}$ Bell, “Connolly and Independence”, 38.

35 Clark, "Commemorating Connolly in 1986", 73.

${ }^{36}$ James Moran, Staging the Easter Rising, 2.

${ }^{37}$ Moran, Staging the Easter Rising, 2.

${ }^{38}$ O’Brien, Ancestral Voices, 116, cited Moran, Staging the Easter Rising, 2.

${ }^{39}$ Moran, Staging the Easter Rising, 3.

${ }^{40}$ Lia Mills, Fallen. 
${ }^{41}$ C. Day Lewis, “Kilmainham Jail: Easter Sunday, 1966”, 59

${ }^{42}$ Day Lewis, “Kilmainham Jail: Easter Sunday, 1966”, 59.

${ }^{43}$ James Connolly, "Call to Arms".

${ }^{44}$ V. I. Lenin, “The Irish Rebellion of 1916”; Leon Trotsky, “On the Events in Dublin”.

${ }^{45}$ Roland Quinault, “The Cult of the Centenary, c.1784-1914”, 318. 